\title{
Plasma $\beta$-Endorphin and Cortisol Profiles around Periparturient Period at Stressful Conditions in Egyptian Buffalo
}

\author{
Abed El-Hady HA ${ }^{1}$, El-Malky OM², Mourad RS ${ }^{1}$, Al-Gezery IS ${ }^{1}$ \\ ${ }^{1}$ Animal Production Department, Faculty of Agriculture, Menoufia University, Al Minufya, Egypt. \\ ${ }^{2}$ Animal Production Research Institute, Agricultural Research Centre, Dokki, Giza, Egypt. \\ E-mail: efaidallah@gmail.com
}

(received: 22-07-2019; revised: 21-08-2019; accepted: 09-09-2019)

\begin{abstract}
ABSTRAK
Abed El-Hady HA, El-Malky OM, Mourad RS, Al-Gezery IS. 2019. Profil plasma $\beta$-endorphin dan kortisol sekitar periode periparnutrient pada kondisi stres pada kerbau Mesir. JITV 24(3): 87-94. DOI: http://dx.doi.org/10.14334/jitv.v24i3.2003

Penelitian ini bertujuan untuk menentukan hubungan antara gangguan reproduksi berupa stres dengan plasma $\beta$-endorphin dan kortisol pada kerbau saat proses kelahiran. Perubahan parameter ini dapat digunakan sebagai parameter objektif untuk melihat hubungan kondisi stres dengan persalinan. Periode periparturien, sesaat sebelum dan setelah melahirkan, adalah waktu yang sangat krusial bagi sapi perah karena harus menyesuaikan perubahan fisiologis, metabolisme dan endokrin. $\beta$-endorphin dan kortisol dengan cepat meningkat sebagai respon terhadap stres pada sapi. Studi ini menentukan kadar plasma darah $\beta$ endorphin dan kortisol kerbau dengan gangguan reproduksi (distosia dan retensi plasenta) dan skor kondisi tubuh rendah selama periode periparturien. Dua puluh kerbau Mesir multipara pada periode akhir kehamilan digunakan selama dua bulan sebelum kelahiran. Konsentrasi $\beta$-endorphin lebih tinggi pada kelompok gangguan reproduksi. Sedangkan, konsentrasi $\beta$-endorphin adalah 134,9 $\pm 4,8$ untuk RP, 121,3 $\pm 4,9$ untuk distosia, 114,2 $\pm 8,4$ untuk BCS Rendah dan 113,5 $\pm 6,5$ pg/ml untuk kontrol. Pada periode yang lebih dekat proses kelahiran baik plasma $\beta$-endorphin dan kortisol menunjukkan tren peningkatan nilai secara bertahap selama $-2,-1$ hari dan nol waktu di semua kelompok. Hal yang sama juga terlihat pada konsentrasi $\beta$-endorphin dan kortisol pada periode postpartum dengan penurunan nilai yang diamati pada semua kelompok setelah proses kelahiran hingga sebulan atau lebih. Kerbau dengan gangguan reproduksi menunjukkan nilai $\beta$-endorphin dan kortisol yang relatif tinggi. Perbedaan yang signifikan $(\mathrm{P} \leq 0,01)$ diamati antara kelompok. Secara umum, kerbau dengan gangguan reproduksi memiliki dampak yang nyata pada plasma darah $\beta$-endorphin di sekitar proses kelahiran.
\end{abstract}

Kata Kunci: Kerbau, $\beta$-endorphin, Kortisol, Distokia, Retensi Plasenta

\section{ABSTRACT}

Abed El-Hady HA, El-Malky OM, Mourad RS, Al-Gezery IS. 2019. Plasma $\beta$-endorphin and cortisol profiles around periparturient period at stressful conditions in Egyptian buffalo. JITV 24(3): 87-94. DOI: http://dx.doi.org/10.14334/jitv.v24i3.2003

The study purpose was to determine the relationship between reproductive disorders as a stress factor with plasma $\beta$ endorphin and cortisol in buffalo around parturition and changes in these parameters could be used as an objective measure of the stress associated labour. The periparturient period, the period immediately before and after calving, is a challenging time for dairy cattle that must cope with physiological, metabolic and endocrine changes. $\beta$-endorphin and cortisol rapidly increased in response to stress in cattle. The study determined the level of blood plasma $\beta$-endorphin and cortisol of buffalo with reproductive disorders (dystocia and retained placenta) and Low body condition score during periparturient period. Twenty multiparous Egyptian buffalo at late pregnancy period were used for two months before parturition. $\beta$-endorphin concentrations were higher in reproductive disorders groups. Whereas, $\beta$-endorphin concentrations were $134.9 \pm 4.8$ for RP, $121.3 \pm 4.9$ for dystocia, 114.2 \pm 8.4 for Low BCS and $113.5 \pm 6.5 \mathrm{pg} / \mathrm{ml}$ for control. At the closer period around parturition both of plasma $\beta$-endorphin and cortisol followed the same trend toward a gradually increased value during -2,-1days and zero time in all groups. A concomitant trend was noticed in $\beta$-endorphin and cortisol concentrations in postpartum period with values decreased were observed in all groups after parturition continued for month or more. Buffalo with reproductive disorders were showed a high relative values in $\beta$-endorphin and cortisol. Significant differences $(\mathrm{P} \leq 0.01)$ were observed between the groups. Generally, buffaloes with reproductive disorders had a clear impact on blood plasma $\beta$-endorphin around parturition process.

Key words: Buffalo, $\beta$-endorphin, Cortisol, Dystocia, Retained Placenta.

\section{INTRODUCTION}

The periparturient period, defined as the period immediately before and after calving, is a challenging time for dairy cattle that must cope with physiological, metabolic and endocrine changes, as well as a variety of environmental and management-related stressors. Also, these challenges likely contribute to the high incidence of disease observed during the weeks following parturition. Moreover, changes in behavior during the 
period around parturition can be used to identify animals that are ill or at risk of disease (SepúlvedaVaras et al. 2013). Also termed the transition period, is defined as the period from 3 weeks prepartum to 3 weeks postpartum, and is marked by several changes in the endocrine and immune systems in preparation for colostrogenesis, parturition and lactogenesis (Sordillo et al. 2009). Studies have verified that the incidence of metabolic and production-related diseases including milk fever, mastitis, fatty liver disease, ketosis, metritis, hypomagnesemia and abomasal displacements are highest during the periparturient period and complications from dystocia and retained placenta commonly occur (Ribeiro et al. 2013).

$\beta$-endorphin and cortisol rapidly elevate in response to stress in cattle. $\beta$-endorphins are neuropeptides derived from Proopiomelanocortin which is found in the anterior pituitary gland and placenta mRNA (Scott et al. 1993; Ettema \& Santos 2004). Dystocia has been a long-standing problem in animals industry and causes trauma for animals and lead to increased rates of uterine infections, reproductive disorders such as retained placenta (Akar \& Gazioglu 2006). The synthesis of $\beta$ endorphin can be occurred by immune system cells which possess mRNA transcripts for Proopiomelanocortin and T-lymphocytes, and in ovarian follicles, but the relatively low levels found in reproductive tissues indicate that it exerts autocrine or paracrine effects in the ovary (Hamada et al. 1995). Ovarian function can be affected by $\beta$-endorphin by modulating LH and FSH secretions then exerting an inhibiting effect on GnRH secretion (Kaminski et al. 2000). Dairy cows respond with elevated circulating levels of $\beta$-endorphin when placed in an unfamiliar room for milking (Bruckmaier RM et al. 1993). The relationship among changes in $\beta$ endorphin and cortisol levels during stress and whether or not any of these hormonal changes can be used as an objective indicator of stress in buffaloes. Then, it would be beneficial to investigate whether dystocia, retained placenta and Low body condition score stimulate $\beta$ endorphin and cortisol releasing or not.

\section{MATERIALS AND METHODS}

Twenty multiparous Egyptian buffalo cows which belonged to the experimental station of Animal Production Research Institute, Agriculture Research Center, Egypt. Those cows ranged from 400 to $620 \mathrm{~kg}$ live body weight, 5 to 11 years old and 3 to 8 parities at late pregnancy period were used for 2 months before the expected parturition date. From 10 days before the expected birth date the birth canal of each animal was monitored by rectal palpations and the body temperature was checked daily to predict the probable time of parturition. All animals were housed in semi- open pans then they were transferred to the maternity unit before 1 or 2 day of the expected birth date. After delivery dams were subjected to the regular managerial practices of the breeding stock. Follow-up using ultrasound sonar for ovarian activity after birth to study link functions, the growth of ovarian follicles and first ovulation occurs after birth and its association with the occurrence of heat or not.

Parturitions followed during the period extend 4 months extended from October to January. Animals were divided into 4 groups, 5 animals in each one: control group (A): delivered spontaneously at term with no obstetrical assistance. Dystocia group (B): delivery was at term but was accompanied by dystocia. RP group (C): delivery was at term but was accompanied by retained placenta. Low BCS group (D): delivery was at term but animals showed Low body condition score. Blood samples of $10 \mathrm{ml}$ were collected from the jugular vein into clean, dried and heparinized evacuated $10 \mathrm{ml}$ tubes, kept on ice, centrifuged at 2500 rotation/m for 20 minutes to obtain the plasma and stored at $-20^{\circ} \mathrm{C}$ until extraction of $\beta$-endorphin that measured by RIA (Osawa T et al. 1998). Cortisol concentrations quantifyed by enzyme immunoassay (Nakao T et al. 1981).

Samples were collected by a permanent catheter was inserted under local anesthesia provided with an extension tube that was fixed to the neck with adhesive tape. It was, therefore, possible to withdraw blood without having to restrain the animal, as follow: a weekly sample started from 8 months till parturition, a sample at 1-2 days before the expected date of parturition, a sample at 0 times of parturition and 3 hours after delivery and finally; samples at days 1, 3, 5 of parturition and every 10 days until corpus luteum formation that following first ovulation. The day of first ovulation was estimated by determination of plasma progesterone concentration show $\geq 1 \mathrm{ng} / \mathrm{ml}$ and rectal palpation (Mourad 2017).

Data were statistically analyzed using descriptive statistics, ANOVA and Duncan test was used to determine the significant differences among means at $\alpha=0.05$ via SAS computer program (SAS 2003).

\section{RESULTS AND DISCUSION}

\section{$\beta$-endorphin and Cortisol at late pregnancy period}

Alterations in plasma $\beta$-endorphin and cortisol levels during the late pregnancy period at 2 months before parturition in the different experimental groups were shown in Table $1 \mathrm{a} \& 1 \mathrm{~b}$. Results revealed to a gradually increased in plasma $\beta$-endorphin value reaching a maximum level during the end of the third trimester in association with the approach of parturition and/or labor pains. Reproductive disorders groups RP 
Table 1a. Plasma $\beta$-endorphin during pregnancy period ( $3^{\text {rd }}$ trimester) in buffalo

\begin{tabular}{|c|c|c|c|c|c|c|c|c|}
\hline \multirow{4}{*}{ Groups } & \multicolumn{8}{|c|}{$\beta$-endorphin concentration $(\mathrm{pg} / \mathrm{ml})$} \\
\hline & \multicolumn{8}{|c|}{ Number of Weeks before parturition (Mean \pm SE) } \\
\hline & \multicolumn{4}{|c|}{ Two months before parturition } & \multicolumn{4}{|c|}{ One month before parturition } \\
\hline & $8^{\text {th }} w$ & $7^{\text {th }} \mathrm{w}$ & $6^{\text {th }} w$ & $5^{\text {th }} \mathrm{w}$ & $4^{\text {th }} \mathrm{w}$ & $3^{\text {th }} w$ & $2^{\text {nd }} \mathrm{w}$ & $1^{\text {st }} \mathrm{W}$ \\
\hline Control & $105.7 \pm 5$ & $109.7 \pm 6$ & $109.1 \pm 5$ & $109.9^{\mathrm{b}} \pm 5.5$ & $111.5^{\mathrm{b}} \pm 6.2$ & $114.1^{\mathrm{b}} \pm 6.9$ & $121.8^{\mathrm{b}} \pm 7.9$ & $126.1^{\mathrm{b}} \pm 8$ \\
\hline Dystocia & $106.8 \pm 5$ & $107.6 \pm 6$. & $109.5 \pm 5$ & $117.5^{\mathrm{ab}} \pm 4.7$ & $120.4^{\mathrm{ab}} \pm 6$ & $125.2^{\mathrm{ab}} \pm 6$ & $136.9^{\mathrm{ab}} \pm 3.3$ & $146.4^{\mathrm{ab}} \pm 2$ \\
\hline $\mathrm{RP}$ & $116.5 \pm 5$ & $121.6 \pm 5$. & $125.9 \pm 5$ & $133.9^{\mathrm{a}} \pm 5.7$ & $137.6^{\mathrm{a}} \pm 4.7$ & $140.5^{\mathrm{a}} \pm 5.9$ & $144.0^{\mathrm{a}} \pm 3.1$ & $159.0^{\mathrm{a}} \pm 2$ \\
\hline Low BCS & $102.8 \pm 7$ & $109.8 \pm 7$ & $110.3 \pm 7$ & $106.0^{\mathrm{b}} \pm 8.0$ & $113.3^{\mathrm{b}} \pm 6.9$ & $118.0^{\mathrm{b}} \pm 8.4$ & $125.2^{\mathrm{ab}} \pm 9.8$ & $127.9^{\mathrm{b}} \pm 1$ \\
\hline $\mathrm{P}$-value & 0.45 & 0.40 & 0.18 & 0.03 & 0.03 & 0.04 & 0.04 & 0.01 \\
\hline
\end{tabular}

Table 1b. Plasma Cortisol during pregnancy period ( $3^{\text {rd }}$ trimester) in buffalo

\begin{tabular}{|c|c|c|c|c|c|c|c|c|}
\hline \multirow{4}{*}{ Groups } & \multicolumn{8}{|c|}{ Cortisol concentration $(\mathrm{ng} / \mathrm{ml})$} \\
\hline & \multicolumn{8}{|c|}{ Number of Weeks before parturition (Mean \pm SE) } \\
\hline & \multicolumn{4}{|c|}{ Two months before parturition } & \multicolumn{4}{|c|}{ one month before parturition } \\
\hline & $8^{\text {th }} \mathrm{W}$ & $7^{\text {th }} \mathrm{w}$ & $6^{\text {th }} w$ & $5^{\text {th }} \mathrm{W}$ & $4^{\text {th }} \mathrm{W}$ & $3^{\text {th }} \mathrm{w}$ & $2^{\text {nd }} \mathrm{W}$ & $1^{\mathrm{st}} \mathrm{W}$ \\
\hline Control & $19.8^{\mathrm{b}} \pm 1.4$ & $19.8^{\mathrm{b}} \pm 1.6$ & $21.2^{\mathrm{b}} \pm 1.4$ & $22.6 \pm 1.4$ & $23.8^{\mathrm{c}} \pm 1.2$ & $24.8^{\mathrm{c}} \pm 1.9$ & $19.2^{\mathrm{b}} \pm 1.4$ & $18.8^{\mathrm{c}} \pm 0.7$ \\
\hline Dystocia & $25.6^{\mathrm{a}} \pm 0.9$ & $23.4^{\mathrm{ab}} \pm 0.9$ & $25.4^{\mathrm{ab}} \pm 0.5$ & $23.2 \pm 1.6$ & $35.0^{\mathrm{b}} \pm 2.7$ & $36.6^{\mathrm{a}} \pm 2.2$ & $32.0^{\mathrm{a}} \pm 2.3$ & $32.8^{\mathrm{b}} \pm 2.1$ \\
\hline $\mathrm{RP}$ & $25.0^{\mathrm{a}} \pm 1.4$ & $25.2^{\mathrm{a}} \pm 1.3$ & $26.4^{\mathrm{a}} \pm 2.1$ & $25.8 \pm .6$ & $41.0^{\mathrm{a}} \pm 1.8$ & $31.6^{\mathrm{b}} \pm 1.2$ & $34.2^{\mathrm{a}} \pm 3.3$ & $41.2^{\mathrm{a}} \pm 2.0$ \\
\hline Low & $21.4^{\mathrm{b}} \pm 1.1$ & $20.6^{\mathrm{b}} \pm 1.2$ & $21.4^{\mathrm{ab}} \pm 1.9$ & $23.4 \pm 1.3$ & $28.4^{\mathrm{c}} \pm 1.3$ & $25.2^{\mathrm{c}} \pm 0.9$ & $24.0^{\mathrm{b}} \pm 1.1$ & $23.0^{c} \pm 1.3$ \\
\hline $\mathrm{P}$-value & 0.01 & 0.03 & 0.07 & 0.62 & 0.00 & 0.00 & 0.00 & 0.00 \\
\hline
\end{tabular}

Table 2a. Plasma $\beta$-endorphin around parturition period (periparturient) in buffalo

\begin{tabular}{cccccccc}
\hline \hline & \multicolumn{5}{c}{$\beta$-endorphin concentration $(\mathrm{pg} / \mathrm{ml})$} \\
\cline { 2 - 7 } Groups & \multicolumn{7}{c}{ Times around parturition (Mean \pm SE) } \\
\cline { 2 - 7 } & \multicolumn{2}{c}{ Before parturition } & during & \multicolumn{5}{c}{ After parturition } \\
\cline { 2 - 7 } & -2 days & -1 day & Zero time & $3 \mathrm{~h}$. & 1 day & 3 days & 5 days \\
\hline Control & $117.4^{\mathrm{c}} \pm 5.2$ & $123.3^{\mathrm{b}} \pm 5.6$ & $127.6^{\mathrm{bc}} \pm 6.4$ & $124.7^{\mathrm{c}} \pm 6.3$ & $94.4^{\mathrm{d}} \pm 4.5$ & $81.7^{\mathrm{d}} \pm 1.6$ & $77.5^{\mathrm{d}} \pm 1.9$ \\
Dystocia & $130.0^{\mathrm{b}} \pm 1.4$ & $133.3^{\mathrm{b}} \pm 3.1$ & $146.9^{\mathrm{b}} \pm 1.7$ & $146.5^{\mathrm{b}} \pm 0.5$ & $145.9^{\mathrm{b}} \pm 1.2$ & $137.5^{\mathrm{b}} \pm 1.6$ & $127.8^{\mathrm{b}} \pm 1.7$ \\
RP & $140.4^{\mathrm{a}} \pm 2.5$ & $149.8^{\mathrm{a}} \pm 8.4$ & $169.0^{\mathrm{a}} \pm 2.2$ & $168.2^{\mathrm{a}} \pm 2.4$ & $164.5^{\mathrm{a}} \pm 0.9$ & $160.6^{\mathrm{a}} \pm 2.7$ & $152.4^{\mathrm{a}} \pm 1.8$ \\
Low & $123.6^{\mathrm{bc}} \pm 3.1$ & $126.1^{\mathrm{b}} \pm 2.2$ & $137.6^{\mathrm{c}} \pm 2.1$ & $134.0^{\mathrm{d}} \pm 1.6$ & $123.5^{\mathrm{c}} \pm 1.7$ & $120.2^{\mathrm{c}} \pm 2.1$ & $119.1^{\mathrm{c}} \pm 2.2$ \\
$\mathrm{P}-$ value & 0.00 & 0.01 & 0.00 & 0.00 & 0.00 & 0.00 & 0.00 \\
\hline a, b Means bearing different superscripts in the same column are significantly different $(\mathrm{P}<0.05)$ &
\end{tabular}

Table 2b. Plasma cortisol around parturition period (periparturient) in buffalo

\begin{tabular}{lccccccc}
\hline & \multicolumn{5}{c}{ Cortisol concentration (ng/ml) } \\
\cline { 2 - 7 } Groups & \multicolumn{5}{c}{ Times around parturition (Mean \pm SE) } \\
\cline { 2 - 7 } & \multicolumn{2}{c}{ Before parturition } & during & \multicolumn{4}{c}{ After parturition } \\
\cline { 2 - 7 } & -2 days & -1 day & Zero time & $3 \mathrm{~h}$. & 1 day & 3 days & 5 days \\
\hline Control & $20.0^{\mathrm{d}} \pm 0.7$ & $21.8^{\mathrm{d}} \pm 0.7$ & $30.6^{\mathrm{b}} \pm 0.2$ & $24.0^{\mathrm{d}} \pm 1.5$ & $20.4^{\mathrm{d}} \pm 0.5$ & $18.4^{\mathrm{d}} \pm 0.4$ & $19.6^{\mathrm{b}} \pm 0.4$ \\
Dystocia & $35.0^{\mathrm{b}} \pm 1.1$ & $41.4^{\mathrm{b} \pm 1.3}$ & $52.6^{\mathrm{a}} \pm 2.5$ & $47.6^{\mathrm{b}} \pm 1.1$ & $42.8^{\mathrm{b}} \pm 1.9$ & $38.8^{\mathrm{b}} \pm 2.1$ & $35.4^{\mathrm{a}} \pm 1.6$ \\
RP & $42.2^{\mathrm{a}} \pm 1.5$ & $44.4^{\mathrm{a}} \pm 1.0$ & $57.2^{\mathrm{a}} \pm 1.6$ & $53.0^{\mathrm{a}} \pm 0.7$ & $48.0^{\mathrm{a}} \pm 1.1$ & $43.2^{\mathrm{a}} \pm 0.9$ & $38.8^{\mathrm{a}} \pm 1.9$ \\
Low & $26.8^{\mathrm{c}} \pm 1.1$ & $27.8^{\mathrm{c}} \pm 0.6$ & $30.6^{\mathrm{b}} \pm 1.7$ & $28.2^{\mathrm{c}} \pm 0.4$ & $27.4^{\mathrm{c}} \pm 0.8$ & $23.6^{\mathrm{c}} \pm 0.8$ & $20.2^{\mathrm{b}} \pm 0.6$ \\
$\mathrm{P}-$ value & 0.00 & 0.00 & 0.00 & 0.00 & 0.00 & 0.00 & 0.00 \\
\hline a, b Means bearing different superscripts in the same column are significantly different $(\mathrm{P}<0.05)$. &
\end{tabular}


and dystocia showed higher $\beta$-endorphin concentration, started from the $5^{\text {th }}$ week before parturition till the last week before parturition followed by groups Low BCS and control with significant differences at $(\mathrm{P} \leq 0.05)$. Table 1a show the highest values for studied groups RP, Dystocia, Low BCS and control at the last week before parturition were $159.0 \pm 2.5,146.4 \pm 2.8,127.9 \pm 11.0,126.1 \pm 8.1$ $\mathrm{pg} / \mathrm{ml}$, respectively.

Meanwhile, cortisol values showed significant differences at $(\mathrm{P} \leq 0.05)$ between groups in the late pregnancy period. The same trends of $\beta$-endorphin values were notated in cortisol values between studied groups. Table $1 \mathrm{~b}$ show that RP and dystocia groups showed an increased cortisol level as $41.2 \pm 2.0$ and $32.8 \pm 2.1 \mathrm{ng} / \mathrm{ml}$, respectively; at the end of this period close to parturition may be due to stress at the last week of parturition as compared to other groups Low BCS and control as $23.0 \pm 1.3$ and $18.8 \pm 0.7 \mathrm{ng} / \mathrm{ml}$, respectively.

The intensity and duration of the $\beta$-endorphin and cortisol responses were dependent on stress. In farm animals, many factors such as pregnancy, parturition processes and periparturient disorders can be considered a natural event that causes various physiologyical stressors (Sathya et al. 2005). Moreover, cows at the time of parturition exposed to severe stress which resulted in hyper-adrenocortical activity with higher levels of circulating steroids like cortisol and biochemical blood parameters (Hoyer et al. 1990).

In buffaloes, the gradual increase in plasma cortisol value during the prepartum period peaked on the day of calving and could be explained by prepartum anxiety and myometrial contractions associated with the stress of parturition (Sathya et al. 2005). In late pregnancy period, the increased activity of $\beta$-endorphin producing cells either in the pituitary gland, from placenta or due to direct fetal input into whole blood $\beta$-endorphin level may be related to the observed increase in $\beta$-endorphin value (Evans et al. 1986).

In cows at parturition, the stress of labor and delivery doesn't seem to influence plasma $\beta$ endorphin levels in cows and no relation was found between $\beta$-endorphin concentration and type of calving. Whereas, $\beta$-endorphin values in dystocia group tended to be higher than the normal group. Cows with abnormal calving may have more stress than the normal one, leading to an increase of peripheral $\beta$-endorphin level. Besides, there was a concomitantly trend between both of plasma $\beta$ endorphin and cortisol profile (Aurich et al. 1990).

\section{$\beta$-endorphin and Cortisol around, before, at and after parturition}

Table $2 \mathrm{a}$ and $2 \mathrm{~b}$ illustrated the mean values of plasma $\beta$-endorphin and cortisol in blood peripheral of buffalo cows around the labor period. Data showed that both of plasma $\beta$-endorphin and cortisol followed the same trend tendency toward a gradually increased value during the period, started from 2 days and 1 day before parturition till the 0 time of parturition (rupture of the amnion and delivery) in all studied groups as control, dystocia, RP and Low BCS, respectively. Table $2 \mathrm{a}$ and $2 \mathrm{~b}$ show the highest values recorded in abnormal delivery groups RP and dystocia followed by groups Low BCS and control. The values of plasma $\beta$-endorphin were $169.0 \pm 2.2, \quad 146.9 \pm 1.7$, $137.6 \pm 2.1$, and $127.6 \pm 6.4 \mathrm{pg} / \mathrm{ml}$, respectively; and cortisol were 57.2 $\pm 1.6,52.6 \pm 2.5,30.6 \pm 1.7$, and $30.6 \pm 0.2 \mathrm{ng} / \mathrm{ml}$, respectively. Immediately after parturition in $3 \mathrm{~h}$ till 5 days ( 1,3 and 5 days), a decreases values were noticed in both of $\beta$-endorphin and cortisol concentrations. Lowest values in both of $\beta$-endorphin and cortisol concentrations in the periparturient period were significant $(\mathrm{P} \leq 0.05)$ between the studied groups on day 5 after parturition, which groups RP, dystocia, Low BCS and control were $152.4 \pm 1.8,127.8 \pm 1.7,119.1 \pm 2.2$, and $77.5 \pm 1.9$ $\mathrm{pg} / \mathrm{ml}$ for $\beta$-endorphin concentrations and $38.8 \pm 1.9$, $35.4 \pm 1.6,20.2 \pm 0.6$, and19.6 $\pm 0.4 \mathrm{ng} / \mathrm{ml}$ for cortisol concentrations, respectively. These results showed a close association between $\beta$ - endorphin and cortisol levels in buffalo cows through a few days after parturition.

In accordance to the present results, plasma cortisol level increased in both cows showed or not higher levels of $\beta$-endorphin nearest and/ or at calving. Furthermore, in normal parturition cases, a distinguish of $\beta$-endorphin excretion was noticed when the uterine constriction and labor pain increased as a result of amniorrhexis (Osawa Takeshi et al. 2000).

In the periparturient period, a significant alteration in both of $\beta$-endorphin and cortisol levels. Cows with normal parturition reached the highest levels of both 2 hormones after rupture of the amniotic sac directly, while, dystocia group was seen just after parturition. They also suggest that dystocia cows may have suffered intensive stress at the time of parturition rather than any other time resulting in excretion of $\beta$ endorphin into plasma at parturition time. Adding to that, during periparturient period $\beta$-endorphin and cortisol concentrations were higher in dystocia group comparison to normal parturition one and there are no significant differences between groups (Osawa et al. 1998).

In cattle, levels of plasma cortisol are elevated during labor, resulting from the increasing demands for glucocorticoids to initiate the lactation and the fact that estrogen reduces the metabolic clearance rate for cortisol (Aurich et al. 1993). It has been reported that plasma cortisol concentrations showed higher values in cows suffering from dystocia than that with normal parturition (Hydbring et al. 1999). On the other hand, dystocia disorder seems to be more stressful for 
Table 3a. Plasma $\beta$-endorphin at the postpartum period in buffaloes

\begin{tabular}{lcccccc}
\hline & \multicolumn{5}{c}{$\beta$-endorphin concentration $(\mathrm{pg} / \mathrm{ml})$} \\
\cline { 2 - 6 } Groups & $10 \mathrm{~d}$ & $20 \mathrm{~d}$ & $30 \mathrm{~d}$ & $40 \mathrm{~d}$ & $50 \mathrm{~d}$ & $60 \mathrm{~d}$ \\
\cline { 2 - 6 } & $77.2^{\mathrm{c}} \pm 5.2$ & $74.5^{\mathrm{c}} \pm 5.8$ & $74.5^{\mathrm{c}} \pm 5.9$ & $72.2^{\mathrm{c}} \pm 6.5$ & $71.0^{\mathrm{c}} \pm 4.0$ & $70.9^{\mathrm{c}} \pm 5.6$ \\
\hline Control & $120.3^{\mathrm{b}} \pm 1.5$ & $115.1^{\mathrm{b}} \pm 1.6$ & $115.5^{\mathrm{b}} \pm 1.4$ & $117.5^{\mathrm{b}} \pm 2.5$ & $107.6^{\mathrm{a}} \pm 5.8$ & $103.5^{\mathrm{a}} \pm 3.7$ \\
Dystocia & $145.1^{\mathrm{a}} \pm 7.6$ & $136.3^{\mathrm{a}} \pm 5.3$ & $125.6^{\mathrm{a}} \pm 5.6$ & $122.0^{\mathrm{a}} \pm 1.2$ & $122.1^{\mathrm{a}} \pm 2.2$ & $122.1^{\mathrm{a}} \pm 2.1$ \\
RP placenta & $112.3^{\mathrm{b}} \pm 3.9$ & $116.1^{\mathrm{b}} \pm 1.4$ & $114.9^{\mathrm{ab}} \pm 1.4$ & $106.1^{\mathrm{b}} \pm 2.0$ & $106.3^{\mathrm{b}} \pm 1.3$ & $101.8^{\mathrm{b}} \pm 1.5$ \\
Low BCS & 0.00 & 0.00 & 0.00 & 0.00 & 0.00 & 0.00 \\
P - value & 0.00 at the postpartum period per day $($ Mean $\pm \mathrm{SE})$ &
\end{tabular}

${ }_{a, b}$ Means bearing different superscripts in the same column are significantly different $(\mathrm{P}<0.05)$.

Table 3b. Plasma Cortisol at the postpartum period in buffaloes

\begin{tabular}{lcccccc}
\hline \hline \multirow{2}{*}{ Groups } & \multicolumn{5}{c}{ Cortisol concentration (ng/ml) } \\
\cline { 2 - 6 } & $10 \mathrm{~d}$ & $20 \mathrm{~d}$ & $30 \mathrm{~d}$ & $40 \mathrm{~d}$ & $50 \mathrm{~d}$ & $60 \mathrm{~d}$ \\
\cline { 2 - 6 } & $16.4^{\mathrm{c}} \pm 1.1$ & $16.8^{\mathrm{c}} \pm 1.1$ & $20.8^{\mathrm{b}} \pm 0.8$ & $21.2^{\mathrm{b}} \pm 0.7$ & $19.8^{\mathrm{d}} \pm 0.8$ & $21.8^{\mathrm{b}} \pm 1$ \\
Control & $29.2^{\mathrm{b}} \pm 1.2$ & $29.0^{\mathrm{b}} \pm 1.4$ & $35.4^{\mathrm{a}} \pm 2.2$ & $35.0^{\mathrm{a}} \pm 0.8$ & $33.2^{\mathrm{b}} \pm 1.4$ & $36.8^{\mathrm{a}} \pm 1.5$ \\
Dystocia & $37.6^{\mathrm{a}} \pm 1.7$ & $37.6^{\mathrm{a}} \pm 1.9$ & $37.4^{\mathrm{a}} \pm 2.1$ & $36.6^{\mathrm{a}} \pm 1.7$ & $38.0^{\mathrm{a}} \pm 1.1$ & $38.4^{\mathrm{a}} \pm 0.9$ \\
RP & $19.6^{\mathrm{c}} \pm 0.7$ & $20.4^{\mathrm{c}} \pm 1.6$ & $22.0^{\mathrm{b}} \pm 0.7$ & $24.8^{\mathrm{b}} \pm 1.3$ & $25.2^{\mathrm{c}} \pm 2$ & $24.0^{\mathrm{b}} \pm 1.6$ \\
Low BCS & 0.00 & 0.00 & 0.00 & 0.00 & 0.00 & 0.00 \\
P-value & 0.00 & &
\end{tabular}

a, b Means bearing different superscripts in the same column are significantly different $(\mathrm{P}<0.05)$.

Table 4a. Plasma $\beta$-endorphin during lactation periods in buffaloes

\begin{tabular}{|c|c|c|c|c|c|c|c|c|}
\hline \multirow{4}{*}{ Groups } & \multicolumn{8}{|c|}{$\beta$-endorphin concentration $(\mathrm{pg} / \mathrm{ml})$} \\
\hline & \multicolumn{8}{|c|}{ Times during lactation period (Mean \pm SE) } \\
\hline & \multicolumn{2}{|c|}{1 month } & \multicolumn{2}{|c|}{2 month } & \multicolumn{2}{|c|}{3 month } & \multicolumn{2}{|c|}{4 month } \\
\hline & $4 \mathrm{w}$ & $2 \mathrm{w}$ & $4 \mathrm{w}$ & $2 \mathrm{w}$ & $4 \mathrm{w}$ & $2 \mathrm{w}$ & $4 \mathrm{w}$ & $2 \mathrm{w}$ \\
\hline Control & $73.1^{\mathrm{c}} \pm 1.9$ & $75.3^{c} \pm 4.1$ & $96.1^{\mathrm{c}} \pm 1.7$ & $96.2^{c} \pm 1.7$ & $107.2^{\mathrm{b}} \pm 4.3$ & $112.2^{\mathrm{a}} \pm 4.2$ & $111.3^{\mathrm{a}} \pm 4.8$ & $112.7^{\mathrm{a}} \pm$ \\
\hline Dystocia & $104.1^{\mathrm{b}} \pm 1.6$ & $107.9^{\mathrm{b}} \pm 1.7$ & $95.9^{c} \pm 1.9$ & $95.5^{\mathrm{c}} \pm 2.3$ & $98.1^{\mathrm{c}} \pm 2.7$ & $97.5^{\mathrm{b}} \pm 2.2$ & $98.7^{\mathrm{b}} \pm 1.9$ & $98.6^{\mathrm{b}} \pm 1$ \\
\hline $\mathrm{RP}$ & $120.5^{\mathrm{a}} \pm 2.4$ & $127.9^{\mathrm{a}} \pm 1.4$ & $119.6^{\mathrm{a}} \pm 2.2$ & $117.3^{\mathrm{a}} \pm 2.1$ & $119.9^{\mathrm{a}} \pm 2.4$ & $119.2^{\mathrm{a}} \pm 2.7$ & $119.2^{\mathrm{a}} \pm 2.7$ & $123.1^{\mathrm{a}} \pm$ \\
\hline Low & $107.2^{\mathrm{b}} \pm 2.5$ & $111.4^{\mathrm{b}} \pm 1.6$ & $101.5^{\mathrm{b}} \pm 1.0$ & $104.1^{\mathrm{b}} \pm 1.3$ & $101.9^{\mathrm{bc}_{ \pm}} \pm 0.7$ & $111.4^{\mathrm{a}} \pm 3.5$ & $111.1^{\mathrm{a}} \pm 4.0$ & $117.6^{\mathrm{a} \pm}$ \\
\hline $\mathrm{P}$-value & 0.00 & 0.00 & 0.00 & 0.00 & 0.00 & 0.00 & 0.01 & 0.00 \\
\hline
\end{tabular}

Table 4b. Plasma Cortisol during lactation periods in buffaloes

\begin{tabular}{|c|c|c|c|c|c|c|c|c|}
\hline \multirow{4}{*}{ Groups } & \multicolumn{8}{|c|}{ Cortisol concentration $(\mathrm{ng} / \mathrm{ml})$} \\
\hline & \multicolumn{8}{|c|}{ Times during lactation period (Mean $\pm \mathrm{SE}$ ) } \\
\hline & \multicolumn{2}{|c|}{1 month } & \multicolumn{2}{|c|}{2 month } & \multicolumn{2}{|c|}{3 month } & \multicolumn{2}{|c|}{4 month } \\
\hline & $4 \mathrm{w}$ & $2 \mathrm{w}$ & $4 \mathrm{w}$ & $2 \mathrm{w}$ & $4 \mathrm{w}$ & $2 \mathrm{w}$ & $4 w$ & $2 \mathrm{w}$ \\
\hline Control & $20.8^{\mathrm{c}} \pm 0.7$ & $20.8^{\mathrm{c}} \pm 0.7$ & $21.6^{\mathrm{c}} \pm 0.9$ & $22.6^{c} \pm 0.6$ & $22.8^{\mathrm{d}} \pm 1.2$ & $24.0^{\mathrm{d}} \pm 0.6$ & $24.8^{\mathrm{d}} \pm 0.6$ & $24.6^{\mathrm{d}} \pm 0.9$ \\
\hline Dystocia & $31.2^{\mathrm{b}} \pm 1.2$ & $31.2^{\mathrm{b}} \pm 1.0$ & $31.4^{\mathrm{b}} \pm 0.7$ & $34.4^{\mathrm{b}} \pm 0.7$ & $34.8^{\mathrm{b}} \pm 1.1$ & $37.8^{\mathrm{b}} \pm 1.4$ & $42.8^{\mathrm{b}} \pm 1.0$ & $43.8^{\mathrm{b}} \pm 1.7$ \\
\hline $\mathrm{RP}$ & $36.8^{\mathrm{a}} \pm 1.3$ & $37.6^{\mathrm{a}} \pm 1.5$ & $38.2^{\mathrm{a}} \pm 1.7$ & $38.2^{\mathrm{a}} \pm 1.2$ & $40.8^{\mathrm{a}} \pm 0.6$ & $42.2^{\mathrm{a}} \pm 0.5$ & $50.4^{\mathrm{a}} \pm 1.5$ & $51.6^{\mathrm{a}} \pm 1.2$ \\
\hline Low & $19.4^{\mathrm{c}} \pm 0.8$ & $20.6^{\mathrm{c}} \pm 0.4$ & $21.2^{\mathrm{c}} \pm 0.4$ & $24.2^{\mathrm{c}} \pm 0.2$ & $28.2^{\mathrm{c}} \pm 0.9$ & $30.2 c \pm 0.7$ & $32.0^{\mathrm{c}} \pm 1.3$ & $32.0^{\mathrm{c}} \pm 1.3$ \\
\hline $\mathrm{P}$-value & 0.00 & 0.00 & 0.00 & 0.00 & 0.00 & 0.00 & 0.00 & 0.00 \\
\hline
\end{tabular}


animals than that the normal one (Heuwieser et al. 1987). Besides, dystocia increases the stress of the cow's health and reproduction (Ettema and Santos 2004).

By the present results, significantly $(\mathrm{P} \leq 0.01)$ higher plasma levels of $\beta$-endorphin in both buffaloes and cows with retained placenta than that with normal animals. They suggested that $\beta$-endorphin would be considered as a factor which probably influences the retention of placenta in farm animals (El-Azab et al. 1988). Moreover, at parturition values of $\beta$-endorphin were higher in cows suffering from dystocia and retained placenta reached up to $79 \%$ in compare with normal one that reached 42\% (Osawa et al. 2000).

Cortisol is a gluconeogenic hormone thereby favoring hyperglycemia at the expense of body proteins, used as an objective indicator for the quantification of stress in cows (Osawa et al. 2000). Also, a markedly increased in plasma glucocorticoid was shown in mammals during parturition (Nakao Toshihiko and Grunert 1990). Similarly, in cattle, levels of plasma cortisol are elevated during labor, resulting from the increasing demands for glucocorticoids to initiate the lactation and the fact that estrogen reduces the metabolic clearance rate for cortisol (Aurich et al. 1993).

\section{$\beta$-endorphin and cortisol during the postpartum period}

Table $3 \mathrm{a}$ and $3 \mathrm{~b}$ showed the concentrations of plasma $\beta$-endorphin and cortisol in postpartum period of buffalo cows. Data illustrated reduces values were observed in all groups after parturition continued for two months in different groups for plasma $\beta$ endorphin with ranged from $145.1 \pm 7.6$ to $122.1 \pm 2.1$, $120.3 \pm 1.5$ to $103.5 \pm 3.7,112.3 \pm 3.9$ to $101.8 \pm 1.5$, and $77.2 \pm 5.2$ to $70.9 \pm 5.6$ but plasma cortisol have slowly increased for two months postpartum and ranged from $37.6 \pm 1.7$ to $38.4 \pm 0.9,29.2 \pm 1.2$ to $36.8 \pm 1.5,19.6 \pm 0.7$ to $24.0 \pm 1.6$, and $16.4 \pm 1.1$ to $21.8 \pm 1$ for groups $\mathrm{RP}$, dystocia, Low BCS and control, respectively. Groups RP and dystocia which suffering from reproductive disorders showed relatively high value in $\beta$-endorphin and cortisol concentrations than that in the other groups Low BCS and control. Highly significant differences $(\mathrm{P} \leq 0.01)$ were observed between the studied groups. All groups were shown the same trend from increases values in plasma $\beta$-endorphin and cortisol levels at the end of postpartum days.

Dystocia significantly elevated cortisol level as compared to normal parturition. Adding that, the rises in the cortisol concentration in dystocia heifers appear to be induced during calving stress (Nakao \& Grunert 1990). The cortisol level during the first stage of parturition was significantly higher in the serum of parturient animals suffering from dystocia (Mohammad \& Abdel-Rahman 2013). In this respect, there is an incidence of powerful acute stress due dystocia followed by an outpouring of ACTH hormone, which in turn caused the adrenal cortex to increase its secretion of glucocorticoids, including cortisol (Kindahl et al. 2002).

\section{$\beta$-endorphin and cortisol concentration during the lactation period:}

Table $4 \mathrm{a}$ and $4 \mathrm{~b}$ represented that there was a very highly significant difference at $(\mathrm{P} \leq 0.001)$ between concentrations of plasma $\beta$-endorphin and plasma Cortisol during lactation periods in buffalo cows. $\beta$ endorphin concentrations and cortisol values increased during lactation periods in buffaloes till the highest values in the fourth month of lactation stage in groups RP, dystocia, Low BCS and control as following: $\quad 51.6 \pm 1.2, \quad 43.8 \pm 1.7, \quad 32.0 \pm 1.3$, and $24.6 \pm 0.9$, respectively. A comparable study showed that $\beta$-endorphin release was not affected by milking frequency and not correlated with the magnitude of prolactin release (Lacasse \& Ollier 2014). Furthermore, milking frequency did not affect cortisol production (O'Driscoll et al. 2012). The increase of cortisol concentrations during milking was not likely induced by ACTH because there were no changes in ACTH concentrations (Tančin et al. 2000), although the control of the adrenal glucocorticoid secretion has generally been supposed to exclusively depend on the release of ACTH (Bruckmaier R \& Wellnitz 2008). A comparison of the results obtained in dairy cows after machine milking with published data showed a similar pattern of cortisol concentrations, with a cortisol increases after milking compared to baseline values (Sutherland \& Huddart 2012). $\beta$-endorphin and cortisol concentration at stages of estrus cycle of buffaloes.

Table $5 \mathrm{a}$ and $5 \mathrm{~b}$ represented that there was a very highly significant difference at $(\mathrm{P} \leq 0.001)$ between concentrations of plasma $\beta$-endorphin and Cortisol in plasma during the estrus cycle stages (Metestrus, Early diestrus, Latediestrus, and Follicular) in buffalo cows. The highest values of plasma $\beta$-endorphin and Cortisol in plasma were found during the Follicular estrus cycle stage in groups RP, dystocia, Low BCS and control of plasma $\beta$-endorphin were $130.7 \pm 2.4$, 130.6 $\pm 2.3,117.0 \pm 3.0$, and 107.2 $\pm 3.6,(\mathrm{pg} / \mathrm{ml})$ and Cortisol values were $51.4 \pm 1.6,43.4 \pm 1.3,32.0 \pm 2.4$, and $24.0 \pm 2.0(\mathrm{ng} / \mathrm{ml})$, respectively for the same groups. This result is comparable to the findings in sheep in which there were different responses of plasma $\beta$-endorphin and cortisol to a change of environment (Fordham et al. 1991). It was reported that in response to acute stress, plasma $\beta$-endorphin, ACTH and cortisol levels in sheep increased and then $\beta$-endorphin declined while ACTH and cortisol levels remained elevated (Shutt et al. 1988). The different profiles of $\beta$-endorphin and cortisol may be related to the half-life of plasma degradation of these two hormones. 
Table 5a. Plasma $\beta$-endorphin at stages of estrus cycle in buffaloes

\begin{tabular}{|c|c|c|c|c|}
\hline \multirow{3}{*}{ Groups } & \multicolumn{4}{|c|}{$\beta$-endorphin concentration $(\mathrm{pg} / \mathrm{ml})$} \\
\hline & \multicolumn{4}{|c|}{ Stages of estrus cycle (Mean \pm SE) } \\
\hline & Metestrus & Early diestrus & Late diestrus & Follicular \\
\hline Control & $98.0^{c} \pm 2.3$ & $103.5^{\mathrm{b}} \pm 3.6$ & $103.4^{\mathrm{c}} \pm 2.7$ & $107.2^{\mathrm{c}} \pm 3.6$ \\
\hline Dystocia & $114.6^{\mathrm{ab}} \pm 4.3$ & $122.0^{\mathrm{a}} \pm 3.6$ & $123.9^{\mathrm{a}} \pm 3.0$ & $130.6^{\mathrm{a}} \pm 2.3$ \\
\hline $\mathrm{RP}$ & $118.6^{\mathrm{a}} \pm 2.4$ & $122.6^{\mathrm{a}} \pm 1.8$ & $128.3^{\mathrm{a}} \pm 1.4$ & $130.7^{\mathrm{a}} \pm 2.4$ \\
\hline Low BCS & $107.9^{\mathrm{b}} \pm 1.9$ & $109.6^{\mathrm{b}} \pm 2.1$ & $112.9^{\mathrm{b}} \pm 3.0$ & $117.0^{\mathrm{b}} \pm 3.0$ \\
\hline $\mathrm{P}$-value & 0.00 & 0.00 & 0.00 & 0.00 \\
\hline
\end{tabular}

Table 5b. Plasma Cortisol at stages of estrus cycle in buffaloes

\begin{tabular}{|c|c|c|c|c|}
\hline \multirow{3}{*}{ Groups } & \multicolumn{4}{|c|}{ Cortisol concentration (ng/ml) } \\
\hline & \multicolumn{4}{|c|}{ Stages of estrus cycle (Mean \pm SE) } \\
\hline & Metestrus & Early diestrus & Late diestrus & Follicular \\
\hline Control & $20.8^{\mathrm{c}} \pm 1.7$ & $22.2^{c} \pm 2.5$ & $22.4^{\mathrm{c}} \pm 1.5$ & $24.0^{\mathrm{d}} \pm 2.0$ \\
\hline Dystocia & $36.0^{\mathrm{b}} \pm 1.2$ & $39.8^{\mathrm{a}} \pm 1.9$ & $42.2^{\mathrm{a}} \pm 1.9$ & $43.4^{\mathrm{b}} \pm 1.3$ \\
\hline $\mathrm{RP}$ & $42.0^{\mathrm{a}} \pm 2.4$ & $43.2^{\mathrm{a}} \pm 2.6$ & $44.4^{\mathrm{a}} \pm 1.3$ & $51.4^{\mathrm{a}} \pm 1.6$ \\
\hline Low BCS & $26.4^{\mathrm{c}} \pm 2.4$ & $29.4^{\mathrm{b}} \pm 2.4$ & $31.2^{\mathrm{b}} \pm 2.8$ & $32.0^{\mathrm{c}} \pm 2.4$ \\
\hline $\mathrm{P}$-value & 0.00 & 0.00 & 0.00 & 0.00 \\
\hline
\end{tabular}

\section{CONCLUSION}

In conclusion, $\beta$-endorphin and cortisol secretion tend to increase at the time of calving. The Opioid system is a subject of attention not only due to its complexity but also its impact on key functions of the organism. Plasma $\beta$-endorphin level in buffalo during pregnancy state increased gradually through the gestation period. It reaches its highest level during the third trimester due to stressful state. Also, it reaches its peak at the time of parturition by appearing its analgesic action. Meanwhile, it decreases gradually towards the re-establishment of the ovarian cycle. It is concluded that $\beta$-endorphin, like oxytocin, is released in an episodic manner during parturition in cows and that both hormones are released concomitantly in conjunction with uterine and abdominal contractions and distension of the uterine cervix.

\section{REFERENCES}

Akar Y, Gazioglu A. 2006. Relationship between vitamin A and beta-carotene levels during the postpartum period and fertility parameters in cows with and without retained placenta. Bull. Vet. Inst. Pulawy. 50:93-96.

Aurich J, Dobrinski I, Hoppen H-O, Grunert E. 1990. $\beta$ Endorphin and met-enkephalin in plasma of cattle during pregnancy, parturition and the neonatal period. J Reprod. Fert. 89:605-612.

Aurich J, Dobrinski I, Hoppen H, Grunert E. 1993. Stimulation of release of $\beta$-endorphin and oxytocin by prostaglandin F2 $\alpha$ in cattle at parturition. Reproduction. J Reprod. Fert. 97:161-166.

Bruckmaier R, Wellnitz O. 2008. Induction of milk ejection and milk removal in different production systems. J Anim. Sci. 86:15-20.

Bruckmaier RM, Schams D, Blum JW. 1993. Milk removal in familiar and unfamiliar surroundings: concentrations of oxytocin, prolactin, cortisol and $\beta-$ endorphin. J Dairy Res. 60:449-456.

El-Azab M, Whitmore H, Kakoma I, Brodie B, McKenna D, Gustafsson B. 1988. Evaluation of the uterine environment in experimental and spontaneous bovine metritis. Theriogenology. 29(6):1327-1334.

Ettema J, Santos J. 2004. Impact of age at calving on lactation, reproduction, health, and income in firstparity Holsteins on commercial farms. J Dairy Sci. 87:2730-2742.

Evans P, Dieguez C, Rees L, Hall R, Scanlon M. 1986. The effect of cholinergic blockade on the ACTH, $\beta$ endorphin and cortisol responses to insulin-induced hypoglycaemia. Clin Endocrinol. 24:687-691.

Fordham D, Al-Gahtani S, Durotoye L, Rodway R. 1991. Changes in plasma cortisol and $\beta$-endorphin concentrations and behaviour in sheep subjected to a change of environment. Anim. Sci. 52:287-296.

Hamada H, Kishioka S, Yamoto M, Nakano R. 1995. [3H] Naloxone binding sites in porcine ovarian follicles and corpora lutea during the ovarian cycle. Eur $\mathbf{J}$ Endocrinol. 132:622-626. 
Heuwieser W, Hartig U, Offeney F, Grunert E. 1987. Significance of glucocorticoids as a parameter of stress in cattle in the periparturient period. J Vet. Medicine, Series A (Germany, FR).

Hoyer C, Grunert E, Jöchle W. 1990. Plasma glucocorticoid concentrations in calves as an indicator of stress during parturition. Am J Vet Res. 51:1882-1884.

Hydbring E, Madej A, MacDonald E, Drugge-Boholm G, Berglund B, Olsson K. 1999. Hormonal changes during parturition in heifers and goats are related to the phases and severity of labour. J Endocrinol. 160:75-86.

Kaminski T, Siawrys G, Bogacka I, Przala J. 2000. The physiological role of beta endorphin in porcine ovarian follicles. Reprod Nutr Dev. 40:63-75.

Kindahl H, Kornmatitsuk B, Königsson K, Gustafsson H. 2002. Endocrine changes in late bovine pregnancy with special emphasis on fetal well-being. Domest Anim Endocrinol. 23:321-328.

Lacasse P, Ollier S. 2014. Effect of premilking stimulation and milking frequency on milking-induced prolactin release in lactating dairy cows. Domest Anim Endocrinol. 47:47-54.

Mohammad DRI, Abdel-Rahman MAM. 2013. A comparative study on behavioral, physiological, and adrenal changes in buffaloes during the first stage of labor with normal and difficult parturition. J Vet Behav. 8:46-50.

Mourad RS. 2017. Plasma chemical composition and progesterone hormone on day of estrus in Egyptian buffalo cows. Buffalo Bulletin. 36:629-637.

Nakao T, Grunert E. 1990. Effects of dystocia on postpartum adrenocortical function in dairy cows. J Dairy Sci. 73:2801-2806.

Nakao T, Tamamura F, Tsunoda N, Kawata K. 1981. Double antibody enzyme immunoassay of cortisol in bovine plasma. Steroids. 38:111-120.

O’Driscoll K, Olmos G, Moya SL, Mee J, Earley B, Gleeson D, O'Brien B, Boyle L. 2012. A reduction in milking frequency and feed allowance improves dairy cow immune status. J Dairy Sci. 95:1177-1187.

Osawa T, Nakao T, Moriyoshi M, Nakada K. 1998. Plasma $\beta$-endorphin around parturition and its relationship to cortisol level and resumption of pituitary and ovarian functions in dairy cows. Anim. Reprod. Sci. 52:27-38.

Osawa T, Nakao T, Moriyoshi M, Nakada K. 2000. Effects of dystocia, retained placenta and body condition on plasma $\beta$-endorphin profile in periparturient dairy cows. J Reprod Dev. 46:23-30.

Ribeiro E, Lima F, Greco L, Bisinotto R, Monteiro A, Favoreto M, Ayres H, Marsola R, Martinez N, Thatcher W. 2013. Prevalence of periparturient diseases and effects on fertility of seasonally calving grazing dairy cows supplemented with concentrates. J Dairy Sci. 96:5682-5697.

SAS. 2003. Statistical Analysis System. Cary NC, SAS Institute Inc.

Sathya A, Prabhakar S, Ghuman S. 2005. Effect of dexamethasone administration on cortisol concentration and biochemical profile in buffaloes suffering from dystocia. Anim Reprod. 2:233-239.

Scott SL, Schaefer AL, Jones SDM, Mears GJ, Stanley RW 1993. Stress indicators and lean tissue yield in transported cattle treated with electrolyte. In: 39th International Congress of Meat Science and Technology, Calgary, Alberta, Canada:1-6, p 22.

Sepúlveda-Varas P, Huzzey J, Weary D, Von Keyserlingk M. 2013. Behaviour, illness and management during the periparturient period in dairy cows. Anim Prod Sci. 53:988-999.

Shutt D, Smith A, Wallace C, Connell R, Fell L. 1988. Effect of Myiasis and Acute Restraint Stress on Plasma Levels of Immunoreactive, B-Endorphin, Adrenocorticotrophin (ACTH) and Cortisol in the Sheep. Aus. J Biol Sci. 41:297-302.

Sordillo LM, Contreras G, Aitken SL. 2009. Metabolic factors affecting the inflammatory response of periparturient dairy cows. Anim Heal Res Rev. 10:5363.

Sutherland M, Huddart F. 2012. The effect of training firstlactation heifers to the milking parlor on the behavioral reactivity to humans and the physiological and behavioral responses to milking and productivity. J Dairy Sci. 95:6983-6993.

Tančin V, Kraetzl W, Schams D, Mihina Š, Hetényi L. 2000. The oxytocin secretion and milk letdown during milking immediately after the change of milking and housing conditions. Veterinarni Medicina. 45:1-4. 